\title{
Governance Mechanisms As Moderators Of Agency Costs In A Pre-SOX Environment
}

Scott E. Miller, Gannon University, USA

\begin{abstract}
Drawing upon the long established stream of agency theory literature, this research investigates the effect of corporate governance mechanisms on agency costs before the passage of the Sarbanes-Oxley Act of 2002, thus questioning the rationale and assumptions made in this legislation. Investigating domestic, manufacturing firms listed on the New York Stock Exchange, this research concludes that many governance controls long held to temper agency conflict did not do so in a pre-SOX environment. Therefore, it is incumbent upon researchers to determine what caused these mechanisms to fail before the passage of SOX. If researchers do not learn from the mistakes of the past and help business understand how they occurred, these mistakes will repeat themselves.
\end{abstract}

Keywords: agency costs

\section{INTRODUCTION}

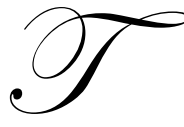

environment.

he purpose of this research was to assess the effectiveness of governance mechanisms long-held to temper agency costs. Specifically, this research focused on domestic firms listed on the New York Stock Exchange (NYSE) in the manufacturing industry in a pre-Sarbanes Oxley Act of 2002 (SOX)

Corporate governance can be defined as a process which delineates "the relationship between a company's shareholders, directors, and management as defined by the corporate charter, bylaws, formal policy, and rule of law" (Gallegos, 2004, p. 37). As noted by Radin and Stevenson (2006), "[c]orporate governance for publicly traded companies is based on the principle that boards are empowered and guided by the law including the Securities Act of 1933, the Securities Exchange Act or 1934, and the Sarbanes-Oxley Act of 2002" (p. 367). It is clear that the requirements of SOX (in addition to other securities laws) attempt to improve the monitoring and bonding activities suggested by Jensen and Meckling (1976) as elements to reducing agency costs. The purpose of this research is to assess the effectiveness of corporate governance in limiting agency costs in U.S. manufacturing firms listed on the NYSE before the passage of SOX.

Drawing on the long standing stream of literature established by Jensen and Meckling (1976) and Fama and Jensen (1983b), the purpose of this research is to assess the need for SOX at the time of its passage from an agency cost perspective. In doing so, this research reviews the effectiveness of corporate governance mechanisms before the passage of SOX. In doing so, this research will determine if improvement was needed in this area before SOX was passed.

This research provides evidence that governance devices long-held to mitigate agency costs were, for the most part, not effective before the passage of SOX and the need for improvement (and possibly regulation) was necessary. It is not the purpose of this research to assess the efficacy of SOX on improving the effectiveness of these governance mechanisms. Rather, as it is oft said that we must learn from history or it is destined to repeat itself, this research is meant to investigate whether these governance mechanisms were effective before the passage of SOX 
and, if not, make a call of further research into the reasons for this result.

\section{METHODOLOGY}

Using a series of univariate and multivariate regression analyses, this research assesses how the change in agency costs from before the passage of SOX through a period after its passage drawing on two common and proven measures of agency cost as outlined by Ang, Cole, and Lin (1999) and further developed by Singh and Davidson (2003). Consistent with the methodology used by Davidson, Bouresli, and Singh (2006), a baseline of agency costs incurred by the firms in the sample was determined using the fiscal year before the passage of SOX was regressed against variables commonly regarded to cause or mitigate agency conflicts. In doing so, the effectiveness of these governance mechanisms on agency costs during the period of interest will be assessed.

\section{LIMITATIONS}

This study, consistent with Botosan (1997), is limited by the fact that the sample used in this study included manufacturing firms in the following SIC codes: 3310-3600. Therefore, the results of this study may only be representative of issues unique to the manufacturing industry and further study beyond this industry may be necessary to impute broader application of this research. Additionally, due to characteristics related to foreign filings, this study was limited to domestic companies in the data set for the SIC codes selected. In addition, due to the different governance requirements imposed by the various stock exchanges, only firms listed on the NYSE were used.

As with any statistical study, this study included the risk of a type I (or $\alpha$ ) and type I (or $\beta$ ) errors (Stock \& Watson, 2007; Gujarati, 2003). Specifically, a type I error (also referred to as an $\alpha$ error or false positive) is one where the model erroneously rejects the null hypothesis which in fact should not be rejected. Put differently, a type I error is one where the independent variables are shown to impact the dependent variable when, in fact, they did not. A type II error (also referred to as a $\beta$ error or false negative) is one where the model erroneously fails to reject the null hypothesis when in fact it should be rejected. More specifically, a type II error is one where the independent variables are found not to impact the dependent variable when, in fact, they do.

It was anticipated, however, that despite these limitations, this research contributes to the streams of literature on agency costs.

\section{LITERATURE REVIEW}

While Berle and Means (1932) first introduced the concept of separation of ownership and control stating "[a]s the ownership of corporate wealth has become more widely dispersed, ownership of that wealth and control over it have come to lie less and less in the same hands" (p. 69); it was Jensen and Meckling (1976) who modeled the theory illustrating that as a manager's ownership in the firm declined, the manager had the propensity to take non-pecuniary benefits which are not beneficial to the firm but generate utility to the manager. Fama (1980) noted "[e]conomists have long been concerned with the incentive problems that arise when decision making in a firm is the province of managers who are not the firm's security holders" (p. 288). Jensen and Meckling defined the agency relationship as "a contract under which one or more persons - the principal(s) - engage another person - the agent to perform some service on their behalf which involves delegating some decision-making authority to the agent" (p. 3 ). These are, as Fama noted, contracts among factors of production. The purpose of bringing these elements of production together on a contractual basis is to achieve cooperation among specialists to achieve productivity for the resource owners (Alchian \& Demsetz, 1972). Fama described the relationships in the firm as a series of contracts citing Alchian and Demsetz who stated:

The essence of the classical firm is identified here as contractual structure with: 1) joint input production; 2) several input owners; 3) one party who is common to all the contracts of the joint inputs; 4) who has the right to renegotiate any input's contract independently of contracts with other input owners; 5) who holds the residual claim; and 6) who has the right to sell his central contractual residual status. The central agent is called the firm's owner and the employer. (Alchian \& Demsetz, p. 794). 
The costs associated with the agency relationship can be classified into three categories, according to Jensen and Meckling (1976): monitoring costs, bonding costs, and residual loss. Monitoring costs include costs of observing the actions of the agent as well as costs to control the agent's behavior through auditing, internal controls, policies and procedures, and restrictions (such as budgets). ${ }^{1}$ Due to their large influence and risk in the firm, Ang, Cole and Lin (2000) noted that large blockholders often fulfill a monitoring role for publicly held corporations since they have the greatest to gain from such monitoring (Holderness \& Sheehan, 1985; Barclay \& Holderness, 1991). Additionally, creditors may incur monitoring costs to protect their investment in the firm, particularly when the creditors have significant amounts lent to the firm (Ang et al.). In doing so, the creditor is ensuring the firm is operating efficiently and utilizing assets effectively (thus controlling the consumption of perquisites by management). This is particularly important, Ang et al. noted, in a highly leveraged firm where the risk of default is higher, increasing the incentive to monitor.

Bonding costs include costs associated with providing assurance to outside owners that the manager's activity related to taking benefits from the company are limited and take the form of audits by public accounting firms, fiduciary bonds (i.e. insurance), and limitations placed on the manager's authority though the contract between the firm and the manager (Jensen \& Meckling, 1976).

The residual loss is defined as the difference between the value to the firm if the manager acted in the best interest of the firm and the decisions the manager ultimately makes (Jensen \& Meckling, 1976) and include "social and private costs of an agent's actions due to incomplete alignment of the agent's and owner's interests" (Ang et al., 2000). ${ }^{2}$ These decisions have been shown to include capital structure, maturity structure, dividend policy, and executive compensation (Ang et al.). According to Jensen and Meckling, the residual loss occurs because management has incentive to consume perquisites ${ }^{3}$ from the firm. When a manager consumes these perquisites the manager benefits from $100 \%$ of their value. While the manager may have some ownership interest in the firm, the manager's loss of profit from this consumption is equal to his or her ownership percentage in the firm times the value of the perquisite consumed. The cost to the remaining shareholders, however, is 1- $\square$ (where $\square$ is the percentage of the firm the manager owns). Therefore, the less ownership interest held by the manager, the greater the benefit of the consumption of the perquisite to the manager and the greater the loss to the remaining shareholders.

The following sections investigate the recent literature which has set out to empirically and directly probe the theories outlined by Jensen and Meckling (1976) and Fama (1980).

\section{Agency Costs and Private Companies}

While Jensen and Meckling's (1976) theories have been largely accepted and widely researched, Ang et al. (2000) maintain that "the actual measurement of the principal variable of interest, agency costs, in both absolute and relative terms, has lagged behind" (p. 81). The reason for this lack of measurement of agency costs has largely been attributed to the difficulty in measuring agency costs (particularly residual loss) and inability to use a zero-agencycost firm as a point of comparison (Davidson, Bouresli, \& Singh, 2006). Ang, et al., using information from National Survey of Small Business Finances, test Jensen and Meckling's as well as Fama's (1980) theories to determine whether the agency problem is more than mere theory. In doing so, Ang et al. sample 1,708 small

\footnotetext{
${ }^{1}$ Competition also makes it necessary to monitor the performance of the management team and individuals (Fama, 1980).

2 The manager may be motivated to make decisions which do not maximize firm value. This case occurs when the manager makes a decision which benefits the manager (financially or non-financially) which is not the optimal decision to maximize firm value. Fama (1980) noted that this divergence of ownership and management creates a situation where the manager, whose motivations may not be parallel with the owners, has little resemblance to Adam Smith's "economic man." Not only do these decisions involve those which result in consumption of perquisites, but also those that result in the shirking of responsibility (Ang, Cole, \& Lin, 2000). However, if the manager is consuming perquisites to maximize the manager's overall utility that may be interpreted as exemplifying Adam Smith's "economic man."

${ }^{3}$ Ellig (2005) noted that perquisites (often referred to as "perks") are a form of compensation that separates top level executives from those below them in the firm. They are often not performance based and create a two class system between the executives and other employees which is contrary to dominant corporate philosophies which stress teamwork in the workplace. Perquisites are a form of compensation which is an extension of and beyond that of the normal benefit package.
} 
corporations. The use of closely-held, private companies allows the researchers to obtain a data sample that includes both firms completely owned by owners ${ }^{4}$ and firms in which managers did not own the entire firm, allowing them to apply Jensen and Meckling's theory in a setting which includes characteristics consistent with the assumptions made in their 1976 work. To measure agency costs, the researchers use two ratios: an expense ratio and an efficiency ratio. The expense ratio is used to measure how effectively management controls costs, including the consumption of perquisites by management (and, thus residual loss to the shareholders). This ratio is defined in Ang et al.'s research as total expenses less cost of goods sold, interest expense and management compensation divided by total sales. The efficiency ratio is total sales divided by total assets (commonly known as the asset turnover ratio). This ratio is used to measure the effectiveness and efficiency of management's deployment and use of firm assets as well as creditor's incentives to monitor. Ang et al. argue a firm will have positive agency costs when the expense ratio is higher due to greater discretionary expenditures or the efficiency ratio is lower due to poor investment decisions or inefficient effort by management. Alternatively, such a situation occur when a firm experiences lower revenues or management consumed perquisites or purchased inefficient assets for the firm, such as lavish office space, office furnishing, automobiles, or resort properties.

Using the expense-to-sales ratio and the asset turnover ratio as dependent variables in identical, but separate, regressions, Ang et al. (2000) perform univariate and multivariate regression analyses using ownership and external monitoring variables. They find that the expense-to-sales ratio is higher and the asset turnover ratio is lower for firms with higher levels of outside ownership than for firms with lower levels of outside ownership. These results directly and empirically supported the theories espoused by Jensen and Meckling (1976) and Fama and Jensen (1983a) that agency costs are, indeed, higher when there is greater outside ownership and lower management ownership.

\section{Agency Costs and Public Companies}

Singh and Davidson (2003) extend Ang et al.'s (2000) research to the publicly held company arena with complementary findings. Extending the concept of managerial ownership used by Ang et al., Singh and Davidson also investigate the role of outside block ownership on agency costs and control for the size and composition of the board of directors to control for the use of alternative governance mechanisms by corporations as indicated by Agrawal and Knoeber (1996). Singh and Davidson use asset turnover to "relate absolute levels of asset utilization efficiencies" by management (p. 794). In addition, they modify the expense ratio used by Ang et al. Specifically, they argued that selling, general, and administrative expenses divided by net sales is a good proxy for agency costs. Unlike Ang et al., Singh and Davidson focused on selling, general, and administrative expense as they represented "the costs related to the management function and to the sale of products, including managerial salaries, rents, insurance, utilities, supplies, and advertising costs" (p. 794). They noted that as these costs increased management consumption of perquisites in terms of lavish expenditures on offices and support services were captured. Davidson et al. (2006) argue the relevance of leaving management compensation in the ratio, arguing excessive pay was an agency cost just like the consumption of perquisites. Since selling, general, and administrative expenses largely reflect discretionary expenditures by managers, Singh and Davidson argue it is a closer proxy for agency costs than the Ang et al. proxy. In addition, Singh and Davidson introduce an independent variable for outside blockholders arguing that these blockholders "may be instrumental in generating superior corporate performance" (p. 796).

Davidson et al. (2006) put Ang et al.'s agency cost measures (efficiency and expense ratios) to the test in public companies in an initial public offering (IPO) setting. Specifically, they ask whether "going public increase or alleviate the agency problem and how various deterrent mechanisms influence agency costs" (p. 88). They used asset turnover as a measure of agency costs arguing asset turnover would be lower when agency conflicts are higher. Consistent with Singh and Davidson (2003), they modify the expense ratio used by Ang et al. They argued that selling, general, and administrative expenses divided by net sales is a better proxy for agency costs. Using IPOs as

\footnotetext{
4 This research does not recognize nor acknowledge that firms owned by managers suffer a unique form of agency costs influenced by the tax code. While, under Jensen and Meckling's theory, as a manager's ownership increases, the manager's incentive to take perquisites from the firm is reduced, it can be argued that, particularly in firms owned solely by managers, managers may attempt to remove pecuniary benefits which are personal in nature from the firm under the guise of business expenses to reduce the overall tax burden to the manager.
} 
their event of interest, Davidson et al. investigate 293 IPO firms and use similar regression equations to Ang et al. in the year before the IPO and the year after the IPO. They did not include the year of the IPO since that year would include significant noise due to the fact that part of the year the firm would have been private and part of the year the firm would have been public.

\section{METHODOLOGY}

In the previous section, a review of the literature related to agency costs. This section develops hypotheses and a model to test whether certain variables found by the literature to affect U.S. firms' agency costs prior to the passage of this comprehensive legislation were doing so during the period before the passage of SOX.

\section{Sample Selection}

In evaluating the impact of disclosure levels on the cost of equity capital, Botosan (1997) notes it is important to choose one industry as disclosure patterns varied among industries. Specifically, she notes that firms in the pharmaceuticals industry would be more likely to make more transparent disclosures about research and development activities than firms in other industries (p. 327). Additionally, Ang, Cole and Lin (2000) note that there are significant differences in agency costs among industries. Therefore, to prevent the influence of industry factors, a single industry is used in this study. Consistent with Botosan's argument, it is argued that different industries may allow for different levels of agency costs. This is acknowledged by Ang, Cole, and Lin (2000), Singh and Davidson (2003), and Davidson, Bouresli, and Singh (2006) when each controlled for industry effects in their studies. Therefore, given Botosan's argument that an intra-industry sample would be appropriate, this research used the same broadly defined manufacturing industry with SIC codes 3310-3600. The use of these manufacturing industry codes allowed for the one measure of agency cost (selling, general, and administrative expense) to be more likely to focus on the perquisites desired in the analysis below as this measure was more likely to include discretionary expenditures.

Consistent with Leuz's (2007) observation that U.S. exchanges have differing governance standards and have experienced changes in each exchange's respective governance standards over the period of interest, the use of one exchange allowed for controlling for this change. Therefore, the firms selected were firms listed on the NYSE for the entirety of the event window. This constraint allowed the results to be read with an understanding of the governance requirements of this exchange on these firms relative to the governance variables examined.

\section{MODEL}

This study uses univariate and multivariate regression with two dependent variables as proxies for agency costs in two separate regressions using the same independent variables. Consistent with Singh and Davidson (2003) and Davidson et al.'s (2006) revision of the proxies developed and proven by Ang et al. (2000), the dependent variables used to proxy for agency costs was sales divided by total assets (asset turnover) and selling, general, and administrative expense as a percentage of sales. Following closely the work of Davidson, Bouresli, and Singh (2006), this study investigated firms in the manufacturing industry using the following model to measure the impact of the governance mechanisms of interest on agency costs:

$\mathrm{ATO}=\beta_{0}+\beta_{1} \mathrm{CEO}+\beta_{2} \mathrm{BH}+\beta_{3} \mathrm{BOARD}+\beta_{4} \mathrm{DIR}+\beta_{5} \mathrm{LEV}+\beta_{6} \mathrm{ASSETS}+\beta_{7} \mathrm{AUDIT}+\beta$

SGA $=\beta_{0}+\beta_{1} \mathrm{CEO}+\beta_{2} \mathrm{BH}+\beta_{3} \mathrm{BOARD}+\beta_{4} \mathrm{DIR}+\beta_{5} \mathrm{LEV}+\beta_{6} \mathrm{ASSETS}+\beta_{7}$ AUDIT $+\beta$

The variables in this model are presented in Table 1. Consistent with Ang et al. (2000), Singh and Davidson (2003), and Davidson et al. (2006), each dependent variable was regressed with each independent variable in a univariate regression to determine the impact of each individual independent variable with a final multivariate

\footnotetext{
${ }^{5}$ Botosan (1997) did not use the entire range, arguing "[e]lectronic components manufactures (SIC codes 3571-3579) are excluded because their disclosure practices may be influenced by the high technology nature of these firms which is quite different from the other firms included in the analysis" (p. 327). Given that this research does not use disclosure level as a component of the research, leaving this range out of the sample would not have been appropriate.
} 
analysis including all the independent variables. Analysis was performed to test the assumption normality of the residuals of the regression through the preparation and review of the related histograms.

\begin{tabular}{|lll|}
\hline & & Table 1: Variables to be used in Data Analysis \\
\hline Dependent Variables & & \\
ATO & $=$ & asset turnover (net sales $\div$ total assets) \\
SGA & & selling, general, and administrative expense $\div$ net sales \\
Independent Variables & & \\
CEO & $=$ & CEO ownership as a percentage of all voting shares outstanding \\
BH & $=$ & blockholder ownership as a percentage of all voting shares outstanding \\
BOARD & $=$ & size of the board of directors (number of directors) \\
DIR & $=$ & outside directors as a percentage of all directors \\
LEV & $=$ & leverage (total debt $\div$ total assets) \\
AUDIT & $=$ & audit fees as a percentage of net sales \\
Control Variables & & \\
\hline ASSETS & &
\end{tabular}

\section{Dependent variables}

As explained in Table 1, each of the dependent variables is used as a single dependent variable in univariate and multivariate regression analyses using identical independent variables known to impact agency costs.

Asset turnover (identified as ATO in the model) was equal to net sales divided by total assets as reported by financial information provided by Compustat. Davidson, Bouresli, and Singh (2006); Ang, Cole and Lin (2000), and Singh and Davidson (2003) used this ratio to measure the effectiveness of management's use of the assets of the firm and, therefore, a measure of agency costs. A lower asset turnover implies management has invested in nonproductive assets which do not generate cash flows and there is, therefore, agency conflict.

Given that a higher asset turnover indicates efficient use of firm assets, a positive coefficient on any of the independent variables when regressed against asset turnover (ATO) indicates a positive impact on the dependent variable and, thus, a decrease in agency costs (since the positive impact would increase the efficiency with which the firm utilized its assets). Conversely, a negative coefficient on any of the independent variables indicates a negative impact on the dependent variable and an increase in agency costs (since the negative impact decreases the efficiency with which the firm utilized its assets).

Selling, general, and administrative expense as a percentage of net sales (identified as SGA in the model) is a ratio which uses total selling, general, and administrative expenses and net sales as reported by financial information provided by Compustat. This variable is expressed as a percentage. The use of a percentage allows this variable to be a relative measure which is, therefore, standardized among various sized firms. A positive coefficient on any of the independent variables when regressed against selling, general, and administrative expense as a percentage of net sales (SGA) indicates an increase in the expense ratio, which is argued to indicate an increase in discretionary expenditures, thus demonstrating an increase in agency costs. A negative coefficient on any of the independent variables would indicate a decrease in the expense ratio which, by virtue of the decrease in discretionary expenditures illustrated thereby, illustrates a reduction in agency costs.

The regression analysis focuses on agency theory as widely documented in prior literature. These tests involved evaluating the statistical significance of the coefficients of each independent variable to determine if each behaves in the model above consistent with agency theory as outlined by Jensen and Meckling's (1976) theory of the firm and its progeny. 


\section{Independent Variables}

Agency Costs and Management Ownership. One basic tenet of Jensen and Meckling's (1976) theory is that the separation of ownership and control creates a divergence of interests between the owner and the manager. The alignment of management ownership and the interest of owners are keys to their argument that there is a positive relationship between management ownership and firm performance (Davidson et al., 2006). Therefore, as noted by DeFond (1992), "the greater the ownership interest of the manager, the more closely aligned his or her preferences are with those of the outside owners" (p. 21). Fama (1980) notes that owners, as the risk bearers, place a bond on their performance by investing funds up front. Owners, therefore, cannot protect themselves individually from these losses, while managers did not have this pecuniary risk outside of the risk of the loss of their employment. While Davidson et al. find support for a positive relationship between management ownership and firm performance, Singh and Davidson (2003) find support for a positive relationship between management ownership and asset utilization but not for management ownership with excess discretionary expenses. Chief executive officer ownership (identified as CEO in the model) is used as a measure of total votes possessed by the CEO expressed as a percentage of the total voting rights in the firm. Brunarski, Harman and Kehr (2004) and Borokhovich, Brunarski, Haman and Kehr (2005) use this as a measure of the disparity of ownership between managers and outside owners, a direct application of the theory espoused by Jensen and Meckling (1976) while Davidson et al. (2006) and Francis and Wilson (1988) use a form of this variable by measuring ownership by various managers and directors. For purposes of this study, the more recent variation using the top manager is used.

Consistent with Brunarski et al. (2004), the CEO was defined as the individual with the title of chief executive officer, president, or chairman of the board of directors with the highest level of direct compensation as reported in the Securities Exchange Commission (SEC) Annual Report (Form 10K). As anticipated by Jensen and Meckling's (1976) theory of the firm, it is hypothesized that the greater the management ownership of the firm, the less incentive to obtain pecuniary benefits from the firm. This first hypothesis is expressed as follows:

$\mathbf{H}_{\mathbf{1}}=$ Agency costs will be inversely related to CEO ownership.

Agency Costs and Blockholders. Ang et al. (2000) note that monitoring costs created a free-rider problem which can cause the agency problem to increase. While some interested parties (whether it be shareholders or creditors) monitor the activities of management, non-monitoring parties enjoy the full benefit of the monitoring. Therefore, while more interested parties wait for other parties to engage in monitoring behavior, agency costs increase due to the lack of or insufficient monitoring. However, due to their large influence and risk in the firm, Ang et al. note that large blockholders often fulfill a monitoring role for publicly held corporations since they have the greatest to gain from such monitoring (Holderness \& Sheehan, 1985; Barclay \& Holderness, 1991).

A blockholder is any shareholder who holds an interest of five percent (5\%) or more of the outstanding shares of stock of the firm. An outside blockholder is one who is not an officer or director of the firm nor a relative of an officer or director. Many researchers have found a positive relationship between the presence of outside blockholders and firm performance (Shome \& Singh, 1995; Allen \& Phillips, 2000; Bethel, Liebeskind, \& Opler, 1998). However, Sing and Davidson (2003) found little support for the same proposition.

Ownership by blockholders (identified as BH in the model) is defined as total votes of outside shareholders with common stock ownership of five percent or more (blockholders) expressed as a percentage of the total voting rights in the firm. Brunarski et al. (2004), Borokhovich et al. (2005), and Davidson et al. (2006) use blockholder ownership as a proxy for the monitoring ability of shareholders based on the previous research indicating that blockholders have a greater interest in monitoring management's behavior to reduce agency costs (see Holderness \& Sheehan, 1985; Barclay \& Holderness, 1991). The theory indicates the greater the presence of large blockholders the greater control, and hence monitoring power, the blockholders have. Therefore, it is hypothesized these blockholders exert this control and monitoring capability in an attempt to reduce agency costs. This hypothesis is stated as follows:

$\mathbf{H}_{2}=$ Agency costs are inversely related to blockholder ownership. 
Agency Costs and Board of Directors. Fama (1980) notes that the ultimate internal monitor of the firm was the board of directors. Fama and Jensen (1983b) argued that outsiders on the board were "the first line of defense in monitoring managers and guarding shareholder's interests" (Davidson et al., 2006, p. 89). Various studies have found support for the notion that outside directors were more effective monitors of management (Coughlan \& Schmidt, 1985; Hermalin \& Weisbach, 1988; Hermalin \& Weisbach, 1991). It might be argued the major securities exchanges in the U.S. concur with this result given that most require a majority of the board membership to be independent. However, Dalton, Daily, Ellstrand, and Johnson (1998) and Baysinger and Butler (1985) found little evidence of a relationship between board composition and firm performance and Singh and Davidson (2003) find no relationship between independent outsiders on the board and a reduction in agency costs. Yet Borokhovich, Brunarski, Harman and Kehr (2005) find that the presence of board independence, not its magnitude, is relevant to shareholders when a firm experiences dividend surprises.

Singh and Davidson (2003) investigate the impact of board size on agency costs, concluding that smaller boards protected shareholders from agency costs and larger boards were associated with efficiency losses. They argue that board size and composition is a complement or substitute for ownership structure on the performance of the firm. However, Singh and Davidson acknowledge the resource dependency theory (Pfeffer, 1973; Pearce \& Zahra, 1992) which indicates a larger board yields benefits from the diversity and broader resource base presented by a larger size, yet they fail to find support for this argument.

Board size (identified as BOARD in the model) is defined as the number of board members as disclosed in the SEC Form 10K. Brunarski et al. (2004) and Borokhovich et al. (2005) use board size as a proxy for the monitoring strength of the board of directors and its impact on agency costs. Research suggests as a board increased in size, there is more oversight over the firm's management. The greater oversight, the less likely agency costs would be present (Pfeffer, 1973; Pearce \& Zahra, 1992). However, Singh and Davidson (2006) find that firms with larger boards are less effective in their monitoring role. Yet, this result is contrary to the accepted theory. This leads to the third hypothesis using the generally accepted theory on board size:

$\mathbf{H}_{3}=$ Agency costs are inversely related to board size.

Outside directors (identified as DIR in the model) are all directors who are not affiliated with the firm, either as members of management or other employees, former employees, or family members of employees. Davidson et al. (2006), Brunarski et al. (2004), Borokhovich et al. (2005), and Belden, Fister and Knapp (2005) use outside directors to proxy for the independence of the board of directors and its propensity to better control management's consumption of perquisites. This variable is calculated as a percentage of total board of directors from the SEC Form 10K for each year of interest. Therefore, the next hypothesis was expressed as follows:

$\mathbf{H}_{4}=$ Agency costs will be inversely related to the proportion of outside directors.

Agency Costs and Financial Leverage. Jensen and Meckling (1976) note that managers may not only transfer wealth from owners but also from creditors. Therefore, as debt increases, there is a greater opportunity for this wealth transfer to take place. As debt increases, managers are constrained and there are fewer resources from which managers could consume perquisites (Davidson et al. 2006). DeFond (1992) notes that it is common for debt instruments to include restrictions which will reduce the propensity for this residual loss (i.e. a bonding mechanism) (see also Singh \& Davidson, 2003). In addition, the cost of the debt (in the form of interest), increases expenses and, therefore, reduces the cash flow available for management to spend on pecuniary benefits.

The degree of leverage (identified as LEV in the model) incurred by the firm was calculated as total debt divided by total assets from information reported by Compustat. Davidson et al. (2006), Brunarski et al. (2004) and Francis and Wilson (1988) used financial leverage to proxy for the availability of funds with which management can make discretionary expenditures for their own benefit. Khanna, Palepu, and Srinivasan (2004) noted that firms with a lower debt to equity ratio (and, therefore, a higher leverage ratio) may disclose more in their financial statements than firms with higher ratios. These firms were more likely to be monitored by their creditors, thereby reducing agency costs. In addition, since managers of firms with greater debt may be more constrained to use a firm's cash on discretionary expenditures for perquisites, there was typically a negative relationship between leverage and agency 
costs. Given the theory used by Davidson et al., Brunarski et al., and Francis and Wilson and supported by Khanna et al. that higher leverage decreases the prevalence of agency costs, boards will use capital structure to control agency costs by maintaining certain levels of leverage to deter management from obtaining perquisites from the firm (Dallas, 1996). This led to the fifth hypothesis tested in this research:

$\mathbf{H}_{5}=$ Agency costs are inversely related to the degree of leverage within the firm.

\section{Control Variables}

Agency Costs and Firm Size. Following Davidson et al. (2006) and Francis and Wilson (1988), both of whom controlled for the size of the firm, the $\log _{10}$ of assets will be used to control for the size of the firm (identified as ASSETS in the model). Ang, Cole and Lin (2000) noted that firm size can result in economies of scale. While Ang et al. did not use a control for firm size because they were working with small corporations and such a control was deemed unnecessary they did find that there were economies of scale in the expense-to-sales ratio when regressed against firm sales. Singh and Davidson (2003) noted that the log form is customarily used on non-negative variables that are characterized by large variances.

Agency Costs and Audit Fees. Neither Ang, Cole and Lin (2000) and its progeny nor other literature studying the agency problem (e.g. Borokhovich, Brunarski, Harman \& Kehr, 2005; DeFond, 1992; Francis \& Wilson, 1988) include audit fees in their models addressing and analyzing the agency problem. In response to the agency problem that can actually be caused by the hiring of the audit firm (Gavious, 2007) it was determined that outflows related to the agency conflict (whether monitoring or bonding) should be included in the model to control for known agency costs which can be measured (i.e. the bonding cost associated with an independent audit). Therefore, audit fees are added to the models as a control variable to determine if a model including audit fees would more appropriately specify the effect of the governance mechanisms on agency costs.

\section{DATA ANALYSIS}

The purpose of this research was to determine whether governance variables moderated agency conflict before the passage of SOX; drawing broadly on agency theory as developed by Jensen and Meckling (1976) and Fama and Jensen (1983b) and the progeny of their work as well as the more recent work of Ang, Cole, and Lin (2000); Singh and Davidson (2003); and Davidson, Bouresli, and Singh (2006).

\section{DATA}

The initial data collected for this research was collected from Compustat for the fiscal year prior to the passage of SOX (July 31, 2001 to June 30, 2002). A compilation of all companies listed on the New York Stock Exchange (NYSE) with SIC Codes of 3310 to 3600 was requested. From this request, data on 133 companies were obtained as the initial sample. For each company, the information listed in Table 2 was requested from Compustat. The information was compiled in a Microsoft Excel 2007 spreadsheet.

Table 2: Data obtained from Compustat

Fiscal Year End

Total Assets

Total Debt

Net Sales

Selling, General, and Administrative Expenses

Audit Fees

SIC Code 
From this data, the following variables were calculated:

- $\quad$ Asset turnover (ATO) was calculated by dividing net sales by total assets.

- $\quad \log _{10}$ of assets (ASSETS) was calculated using the logarithm function in Microsoft Excel 2007.

- $\quad$ Leverage (LEV) was calculated by dividing total debt by total assets.

- $\quad$ Selling, general, and administrative expense as a percentage of net sales (SGA) was calculated by dividing selling, general, and administrative expense by net sales.

- $\quad$ Audit Fees (AUDIT) was calculated as a percentage of net sales.

Once the list of companies in the preliminary data set was determined, additional data was collected manually. The Securities Exchange Commission (SEC) annual report pursuant to section 13 and 15(d) (Form 10-K) or Annual and transition report of foreign private issuers pursuant to sections 13 or 15(d) (Form 20-F), as appropriate, was pulled from the SEC website (www.sec.gov) for each year within the event window for each company listed in the sample provided by Compustat. When appropriate, information was obtained from the annual proxy statement (DEF 14A) when incorporated by reference in the Form 10-K. The data collected from the annual SEC filings for each company is presented in Table 3.

Table 3: Data obtained from Annual SEC Filings

Number of directors

Number of outside directors

Number of voting shares outstanding

Number of voting shares owned by outside blockholders

Number of voting shares owned by CEO

Country of Incorporation

From this information, the following variables were calculated for each year:

- $\quad$ The percentage of outside directors as a percentage of the total board of directors (DIR) was calculated by dividing the total outside directors by the total board members.

- $\quad$ The percentage of blockholder ownership (BH) was calculated by dividing the total voting shares owned by outside blockholders by the total voting shares outstanding.

- $\quad$ The percentage of CEO ownership (CEO) was calculated by dividing the total voting shares owned by the chief executive officer, president, or chairman of the board with the highest level of compensation by the total voting shares outstanding.

The data points analyzed for this research are summarized in Table 4.

\begin{tabular}{|lll|}
\hline & & \multicolumn{1}{c|}{ Table 4: Variables to be used in Data Analysis } \\
\hline Dependent Variables & & \\
ATO & $=$ & $\begin{array}{l}\text { asset turnover (net sales } \div \text { total assets) } \\
\text { selling, general, and administrative expense } \div \text { net sales }\end{array}$ \\
$\frac{\text { Independent Variables }}{\text { CEO }}$ & & \\
BH & $=$ & CEO ownership as a percentage of all voting shares outstanding \\
BOARD & $=$ & blockholder ownership as a percentage of all voting shares outstanding \\
DIR & $=$ & outside directors as a percentage of all directors \\
LEV & $=$ & leverage (total debt $\div$ total assets) \\
AUDIT & $=$ & audit fees as a percentage of net sales \\
Control Variables & & \\
\hline ASSETS & $=$ & $\log _{10}$ of total asset \\
AUDIT & $=$ & audit fees as a percentage of net sales
\end{tabular}




\section{Data Selection}

After compiling the data above, it was necessary to filter the data to have construct validity. Therefore, this study only focused on companies registered with the SEC before and after the passage of SOX as it was important for future research to be able to compare these results to post-SOX results. Nineteen firms fell into the category of firms which had registered or withdrawn registration during this period. Of these nineteen firms, eight filed a registration statement (Form S-1), two filed a registration of securities issued in business combinations (Form S-4), four filed a registration statement of certain foreign private issuers (Form F-1), two filed a registration of securities by foreign private issuers in certain business combinations (form F-4), two filed a prospectus under Rule 424(b)(2) (Form 424B2), and one filed a registration withdrawal request (Form RW). The nineteen firms involved included nine domestic firms and ten foreign firms. This analysis left 114 remaining in the sample from the 133 firms which had been provided by Compustat.

While collecting the governance and ownership data on each firm, it became apparent that many of the foreign firms (specifically the foreign private issuers) did not present the ownership interest of the CEO. In addition, the distinction between inside and outside directors was not apparent for many of the foreign firms. Given that there were 24 foreign firms in the data set and many of the firms did not present CEO ownership and/or the independence of the board was not readily determinable, and considering that ten of the firms had filed the initial registration during the window discussed above, it was determined that the best results would be obtained by focusing on only domestic firms to prevent any outliers that might occur due to differing regulatory requirements for foreign firms (not only SOX requirements, but more specifically, NYSE listing requirements). Given that ten firms had filed an initial registration after the start of the event period, the net reduction in the sample resulting from focusing the study to domestic firms was 14 firms. Therefore, only the 100 domestic firms were left in the sample.

In addition, there were two firms for which the full complement of Compustat data was not available. It was deemed imprudent to include these firms in the data set as determining the data points from the filings would amount to conjecture given that some data points for other reported firms could not be tied directly to the filings. One of these firms had already been eliminated above, therefore, the net reduction in the sample size was one domestic firm from this analysis. This resulted in a total of 99 firms in the remaining sample.

Finally, this study evinced that the inclusion of audit fees as a percentage of net sales in the model would be an appropriate extension of the model developed by Ang et.al (2000) and to control for its impact on agency costs. Given that four firms did not report audit fees for the year before SOX was passed, these firms could not be included in the model. This resulted in a total of 95 firms $(n=95)$ in the final sample used for the remainder of the study.

\begin{tabular}{|c|c|c|c|c|c|}
\hline \multicolumn{6}{|c|}{ Table 5: Descriptive Statistics of Year Before the Passage of SOX } \\
\hline & Mean & Std. Dev. & Median & Min & Max \\
\hline \multicolumn{6}{|l|}{ Dependent Variables } \\
\hline ATO & 1.096 & 0.402 & 1.039 & 0.211 & 3.379 \\
\hline SGA & 0.188 & 0.104 & 0.175 & 0.003 & 0.770 \\
\hline \multicolumn{6}{|l|}{ Independent Variables } \\
\hline $\mathrm{CEO}$ & 0.036 & 0.078 & 0.012 & 0.000 & 0.493 \\
\hline $\mathrm{BH}$ & 0.221 & 0.184 & 0.186 & 0.000 & 0.853 \\
\hline BOARD & 8.800 & 2.587 & 9.000 & 4.000 & 18.000 \\
\hline DIR & 0.768 & 0.140 & 0.800 & 0.286 & 0.929 \\
\hline LEV & 0.280 & 0.180 & 0.268 & 0.000 & 1.441 \\
\hline AUDIT & $0.072 \%$ & $0.055 \%$ & $0.056 \%$ & $0.008 \%$ & $0.315 \%$ \\
\hline ASSETS & 3.089 & 0.570 & 3.077 & 1.833 & 4.513 \\
\hline \multicolumn{6}{|l|}{ Firm Size } \\
\hline Net Sales (in millions) & $3,103.88$ & $6,007.81$ & $1,235.42$ & 70.09 & $45,226.00$ \\
\hline Total Assets (in millions) & $3,281.06$ & $6,460.13$ & $1,193.77$ & 68.07 & $32,584.00$ \\
\hline
\end{tabular}




\section{Descriptive Statistics}

The first step in evaluating the data for the model developed above was to assess the data collected by calculating the descriptive statistics. For all the variables described below, there were 95 observations $(\mathrm{n}=95)$. Descriptive statistics were calculated using SPSS 15.0 for Windows statistical software.

The data from the 95 firms was for the fiscal year before the passage of SOX. Therefore, firm years ended between July 31, 2001 and July 30, 2002 were used. The descriptive statistics for the year are presented in Table 5.

\section{REGRESSION ANALYSIS}

\section{Correlation Results}

As presented in above, the data collected was analyzed in two multivariate regression equations (one regression for each of the two dependent variables using the same regressors). Before regression analysis took place, the data was analyzed for high degrees of bivariate correlation between the dependent and independent variables. Correlation analysis allows the researcher to test for the potential for perfect or imperfect multicollinearity between the variables. The next section discusses the results of this analysis.

\begin{tabular}{|lcccccccc|}
\hline \multicolumn{10}{c|}{ Table 6: Asset Turnover Correlation Matrix } \\
\hline & $\underline{\text { ATO }}$ & $\underline{\text { CEO }}$ & $\underline{\text { BH }}$ & $\underline{\text { BOARD }}$ & $\underline{\text { DIR }}$ & $\underline{\text { LEV }}$ & $\underline{\text { ASSETS }}$ & $\underline{\text { AUDIT }}$ \\
ATO & 1.000 & & & & & & & \\
CEO & 0.039 & 1.000 & & & & & & \\
BH & -0.149 & -0.126 & 1.000 & & & & & \\
BOARD & 0.079 & -0.161 & -0.364 & 1.000 & & & & \\
DIR & 0.138 & -0.329 & 0.149 & 0.121 & 1.000 & & & \\
LEV & -0.144 & -0.099 & 0.262 & -0.084 & 0.081 & 1.000 & & \\
ASSETS & -0.199 & -0.324 & -0.345 & 0.443 & 0.268 & 0.149 & 1.000 & \\
AUDIT & 0.1927 & 0.193 & 0.346 & -0.251 & -0.277 & 0.011 & -0.493 & 1.000 \\
\hline
\end{tabular}

The results of the correlation analysis are presented in the correlation matrices in Tables 6 and 7 which present the Pearson product-moment correlation value $(r)$ between each variable as calculated by SPSS 15.0 for Windows. Table 6 presents the correlation matrix, for the regression of the dependent variable asset turnover (ATO) against the independent variables in the model. Using a conservative critical value of 0.600 , it was noted that there were no high correlation coefficients for this regression analysis. This indicated there was not a high degree of linear relationship (i.e. collinearity) between any two variables in the sample used for this regression analysis. Therefore the risk of multicollinearity was low in this multiple regression model. In fact the highest correlation was 0.443 , well below the critical value.

The correlation matrix for the regression for selling, general, and administrative expenses as a percentage of net sales (SGA) in the year before the passage of SOX is presented in Table 7. Again, using a critical value of 0.600 , there was no correlation coefficient which exceeded the critical value. All of the correlation coefficients between SGA and the independent variables are well below the critical value. Again, as the correlation coefficients between the independent variables were identical in both SGA and ATO, the highest correlation coefficient was 0.443 . The next highest correlation coefficient in this analysis was -0.364 . Therefore, the risk of multicollinearity was minimal in this regression.

Since the correlation analysis indicated the linear relationship between each of the independent variables did not give rise to a meaningful risk of multicollinearity, the next section discusses the results of the regression analyses run for each dependent variable for each year. 


\begin{tabular}{|lccccccccc|}
\hline \multicolumn{10}{c|}{ Table 7: SGA percentage in the Year SOX-1 Correlation Matrix } \\
\hline SGA & $\underline{\text { SGA }}$ & $\underline{\text { CEO }}$ & $\underline{\text { BH }}$ & $\underline{\text { BOARD }}$ & $\underline{\text { DIR }}$ & $\underline{\text { LEV }}$ & $\underline{\text { ASSETS }}$ & $\underline{\text { AUDIT }}$ \\
CEO & 0.031 & 1.000 & & & & & & \\
BH & 0.134 & -0.126 & 1.000 & & & & & \\
BOARD & -0.059 & -0.161 & -0.364 & 1.000 & & & & \\
DIR & -0.150 & -0.329 & 0.149 & 0.121 & 1.000 & & & \\
LEV & -0.117 & -0.099 & 0.262 & -0.084 & 0.081 & 1.000 & & \\
ASSETS & -0.135 & -0.324 & -0.345 & 0.443 & 0.268 & 0.149 & 1.000 & \\
AUDIT & 0.564 & 0.193 & 0.346 & -0.251 & -0.277 & 0.011 & -0.493 & 1.000 \\
\hline
\end{tabular}

\section{Regression Results}

The first series of regression analyses performed were those with asset turnover (ATO) as the dependent variable. The first step in the data analysis was to regress each independent variable in a univariate regression against the dependent variable and the second was to include all the independent variables in a multivariate regression model. It should be noted that the histograms of the residuals for each univariate and the multivariate analysis approached a normal distribution and were homoscedastistic and, therefore, meet these crucial assumption of regression analysis.

The results of these univariate and multivariate tests for are summarized in Table 8 . When preparing the univariate tests, only the control variable $\log _{10}$ of assets (ASSETS) (at the 5\% level of confidence) and AUDIT (at the $10 \%$ level) were statistically significant. However, it was expected that ASSETS would be statistically significant given that dependent variable, asset turnover, is a function of total assets from which the ASSETS independent variable was derived by calculating the logarithm of total assets to the base ten $\left(\log _{10}\right)$. The adjusted $\mathrm{r}$ squared ${ }^{6}\left(\mathrm{R}^{2}\right)$ on the univariate analyses using the independent variables CEO ownership (CEO) and board size (BOARD) (both of which had coefficients which were not statistically significant) were negative indicating that, when these variables were used as independent variables in a univariate test and regressed against asset turnover (ATO), the resulting adjusted coefficient of determination (adjusted $\mathrm{R}^{2}$ ) was less than that which could be expected to occur by mere chance.

When the independent variables were placed in the full regression model, however, the variables appeared to control for each other. The coefficient of the blockholder ownership (BH) independent variable was statistically significant at the $10 \%$ level of confidence. Interestingly, the coefficient was negative which was the opposite of the anticipated result. This decline in ATO indicated the firms utilized assets less efficiently and thus experienced an increase in agency costs. In addition, the level of director independence (DIR) was statistically significant at the 5\% confidence level. The coefficient of this variable was positive which was consistent with the expected result and the board's monitoring role in the firm. Given that ATO increased, the firms utilized assets more efficiently and, therefore, agency costs declined. As anticipated, the $\log _{10}$ of assets (ASSETS) variable was statistically significant at the $1 \%$ level of confidence and had a negative effect on ATO. This was to be expected given that assets is the denominator of the dependent variable and, therefore, an increase in assets would cause the dependent variable to decline when it is above one. ${ }^{7}$ Additionally, as anticipated, the audit fee (AUDIT) independent variable was

\footnotetext{
${ }^{6}$ Adjusted $\mathrm{R}^{2}$ was used throughout this study as the sample did not include the entire population of the data being studies. The adjusted $R^{2}$ is a modification of the coefficient of determination $\left(\mathrm{R}^{2}\right)$ and corrects the coefficient of determination (which is a measurement of the goodness of fit of the model) for the sample size and number of regressors. This, in turn, adjusts for the amount of the model that might be occurring by chance rather than as determined by the independent variables included in the model. While $\mathrm{R}^{2}$ is a measure of the goodness of fit, it is only the explained and unexplained variation in the dependent variable while not accounting for the degrees of freedom (Pindyk and Rubinfeld, 1998). As noted by Pindyk and Rubinfeld, adjusted $\mathrm{R}^{2}$ can rise or fall with the inclusion of additional variables, thereby eliminating the incentive to add variables to simply increase the coefficient of determination as can occur with $\mathrm{R}^{2}$.

${ }^{7}$ This analysis only holds true when ATO is above one. If ATO is less than one, a decline in the denominator would cause ATO to increase.
} 
statistically significant at the $5 \%$ level of confidence. The coefficient was negative, indicating that as audit fees increased, the efficiency with which the firm utilized assets declined which is contrary to the expected result. The adjusted $\mathrm{R}^{2}$ was still considerably low in the full model; however, it was higher than those in any of the univariate tests indicating the inclusion of the variables in the multivariate model have added to the explanatory power of the independent variables. In addition, the adjusted $\mathrm{R}^{2}$ was greater than that obtained in the Ang et al. (2000) research when utilizing asset turnover (ATO) as the dependent variable.

\begin{tabular}{|c|c|c|c|c|c|c|c|c|}
\hline \multicolumn{9}{|c|}{ Table 8: Regression Results - ATO } \\
\hline & $\underline{1}$ & $\underline{2}$ & $\underline{3}$ & $\underline{4}$ & $\underline{5}$ & $\underline{6}$ & $\underline{7}$ & $\underline{8}$ \\
\hline Intercept & 1.089 & 1.168 & $0 . \overline{9} 88$ & $0 . \overline{7} 92$ & $1 . \overline{186}$ & 1.531 & 1.196 & 1.863 \\
\hline t-statistic & $\begin{array}{c}23.794 \text { * } \\
0.000\end{array}$ & $\begin{array}{c}18.121 \\
0.000\end{array}$ & $\begin{array}{l}6.699 \\
0.000\end{array}$ & $\begin{array}{l}3.429 \neq \\
0.001\end{array}$ & $\begin{array}{c}15.547 \\
0.000\end{array}$ & $\begin{array}{l}6.797 * \\
0.000\end{array}$ & $\begin{array}{c}17.732 \ddagger \\
0.000\end{array}$ & $\begin{array}{l}5.023 * \\
0.000\end{array}$ \\
\hline CEO & 0.200 & & & & & & & -0.083 \\
\hline t-statistic & 0.375 & & & & & & & -0.153 \\
\hline$p$-value & 0.709 & & & & & & & 0.879 \\
\hline $\mathrm{BH}$ & & -0.327 & & & & & & -0.478 \\
\hline$t$-statistic & & -1.455 & & & & & & $-1.814^{*}$ \\
\hline$p$-value & & 0.149 & & & & & & 0.073 \\
\hline BOARD & & & 0.012 & & & & & 0.021 \\
\hline$t$-statistic & & & 0.767 & & & & & 1.255 \\
\hline$p$-value & & & 0.445 & & & & & 0.213 \\
\hline DIR & & & & 0.397 & & & & 0.619 \\
\hline t-statistic & & & & 1.341 & & & & $2.018^{\dagger}$ \\
\hline$p$-value & & & & 0.183 & & & & 0.047 \\
\hline LEV & & & & & -0.321 & & & -0.024 \\
\hline t-statistic & & & & & -1.399 & & & -0.107 \\
\hline$p$-value & & & & & 0.165 & & & 0.915 \\
\hline ASSETS & & & & & & -0.141 & & -0.377 \\
\hline t-statistic & & & & & & $-1.963^{*}$ & & $-4.175 *$ \\
\hline$p$-value & & & & & & 0.053 & & 0.000 \\
\hline AUDIT & & & & & & & -138.695 & -205.157 \\
\hline$t$-statistic & & & & & & & $-1.862 *$ & $-2.456^{\dagger}$ \\
\hline$p$-value & & & & & & & 0.066 & 0.016 \\
\hline Adjusted $\mathrm{R}^{2}$ & -0.009 & 0.012 & -0.004 & 0.008 & 0.010 & 0.029 & 0.026 & 0.172 \\
\hline & & \$significant & at 0.01 & gnificant a & $0.05 \quad$ sis & ificant at 0.1 & & \\
\hline
\end{tabular}

The results of these univariate and multivariate tests for the regression models with SGA as the dependent variable are summarized in Table 9. When preparing the univariate tests, only the audit fee (AUDIT) variable was statistically significant. This result is to be expected given that audit fees are part of the numerator of the dependent variable. The adjusted $\mathrm{R}^{2}$ of the CEO ownership (CEO) and board size (BOARD) variables were each negative, indicating that the resulting adjusted $\mathrm{R}^{2}$ was lower than would be expected to conclude that the regression results were anything different from that which might occur randomly. 


\begin{tabular}{|c|c|c|c|c|c|c|c|c|}
\hline \multicolumn{9}{|c|}{ Table 9: Regression Results - SGA in the year SOX-1 } \\
\hline & 1 & $\underline{2}$ & $\underline{3}$ & 4 & $\underline{5}$ & $\underline{6}$ & $\underline{7}$ & $\underline{8}$ \\
\hline Intercept & 0.186 & 0.171 & 0.209 & 0.274 & 0.207 & 0.264 & 0.111 & 0.019 \\
\hline $\begin{array}{l}\text { t-statistic } \\
\text { p-value }\end{array}$ & $\begin{array}{c}15.780 \\
0.000\end{array}$ & $\begin{array}{c}10.262 \\
0.000\end{array}$ & $\begin{array}{l}5.474 \\
0.000\end{array}$ & $\begin{array}{l}4.601 \\
0.000\end{array}$ & $\begin{array}{c}10.467 \\
0.000\end{array}$ & $\begin{array}{l}4.489{ }^{\ddagger} \\
0.000\end{array}$ & $\begin{array}{l}7.583^{\ddagger} \\
0.000\end{array}$ & $\begin{array}{l}0.215 \\
0.830\end{array}$ \\
\hline CEO & 0.041 & & & & & & & -0.069 \\
\hline $\begin{array}{l}\text { t-statistic } \\
\text { p-value }\end{array}$ & $\begin{array}{l}0.295 \\
0.769\end{array}$ & & & & & & & $\begin{array}{r}-0.540 \\
0.591\end{array}$ \\
\hline $\mathrm{BH}$ & & 0.076 & & & & & & 0.010 \\
\hline $\begin{array}{l}t \text {-statistic } \\
\text { p-value }\end{array}$ & & $\begin{array}{l}1.301 \\
0.197\end{array}$ & & & & & & $\begin{array}{l}0.167 \\
0.868\end{array}$ \\
\hline BOARD & & & -0.002 & & & & & 0.000 \\
\hline$t$-statistic & & & -0.566 & & & & & 0.019 \\
\hline p-value & & & 0.573 & & & & & 0.985 \\
\hline DIR & & & & -0.112 & & & & -0.022 \\
\hline$t$-statistic & & & & -1.465 & & & & -0.306 \\
\hline$p$-value & & & & 0.146 & & & & 0.760 \\
\hline LEV & & & & & -0.068 & & & -0.095 \\
\hline$t$-statistic & & & & & -1.136 & & & $-1.787^{*}$ \\
\hline p-value & & & & & 0.259 & & & 0.077 \\
\hline ASSETS & & & & & & -0.025 & & 0.039 \\
\hline$t$-statistic & & & & & & -1.314 & & $1.857^{*}$ \\
\hline$p$-value & & & & & & 0.192 & & 0.067 \\
\hline AUDIT & & & & & & & 106.542 & 126.159 \\
\hline$t$-statistic & & & & & & & $6.592 \ddagger$ & 6.466 \\
\hline p-value & & & & & & & 0.000 & 0.000 \\
\hline Adjusted $\mathrm{R}^{2}$ & -0.010 & 0.007 & -0.007 & 0.012 & 0.003 & 0.008 & 0.311 & 0.322 \\
\hline & & ${ }_{\text {Significan }}$ & at 0.01 & ignificant a & $0.05^{*} \mathrm{sig}$ & ificant at 0 & & \\
\hline
\end{tabular}

When the independent variables were placed in the full regression model for selling, general, and administrative expenses as a percentage of net sales (SGA), the independent variables did not appear to control for each other. The adjusted $\mathrm{R}^{2}$ increased very slightly from that in the AUDIT univariate model. It is noteworthy that the coefficient of the ASSETS, which was used in the model as control variables, was significant in only the multivariate model. The audit fee (AUDIT) variable, however, was significant in the multivariate model indicating it was an effective control variable. The only other independent variable which was an effective moderator of agency costs, as measured by discretionary expenditures, was leverage (LEV) which had the expected, negative, impact on SGA.

\section{ANALYSIS OF RESULTS}

This section outlines the conclusions drawn from the econometric analyses performed above. Each hypothesis developed is addressed individually based on these results. Each hypothesis tested a different variable which the literature indicated would mitigate the agency conflict.

The first hypothesis $\left(\mathrm{H}_{1}\right)$ was that agency costs were inversely related to CEO ownership. The coefficients of the CEO ownership (CEO) variable for each univariate and multivariate model with both dependent variables were not statistically significant. Given that the coefficients of the CEO variable were not significant in all but one model, this hypothesis was rejected in this data set for the time period covered. 
The second hypotheses $\left(\mathrm{H}_{2}\right)$ relates to ownership of company stock by outside blockholders. It states agency costs are inversely related to blockholder ownership. The blockholder ownership (BH) variable was statistically significant $(p<10 \%)$ when placed in the multivariate model with asset turnover (ATO) as the dependent variable. In this model, the coefficient of the BH variable $\left(\beta_{2}\right)$ was negative, indicating that the efficiency of asset utilization decreased as blockholder ownership increased (i.e. agency costs increased, due to the lack of efficient asset utilization, as blockholder ownership increased). Under agency theory a negative, statistically significant coefficient would be expected in each year in the selling, general, and administrative expenses as a percentage of net sales (SGA) model if blockholders were controlling for expenditures for the pecuniary benefit of the manager. Therefore, given the lack of statistical significance of the coefficients, the second hypothesis was rejected, in general, as BH did not affect for either measure of agency cost, as predicted.

The third hypothesis $\left(\mathrm{H}_{3}\right)$ stated that agency costs were inversely related to board size. While the coefficient of the board size (BOARD) variable was not statistically significant in either univariate or multivariate model when regressed against either ATO or SGA. Therefore, the third hypothesis was rejected as there was not consistent econometric evidence that the board's monitoring of agency costs was statistically significant.

The fourth hypothesis $\left(\mathrm{H}_{4}\right)$ stated that agency costs would be inversely related to board independence which was proxied by the proportion of outside directors to total directories. While the degree of board independence had a statistically significant $(p<5 \%)$ effect on agency costs as measured by asset turnover (ATO) in the multivariate model and was positive, as expected, yet it did not have a statistically significant effect on agency costs in either univariate or the multivariate model for SGA. Given these results, the fourth hypothesis was rejected as outside directors (DIR) did not have a statistically significant effect on agency costs in three of the four models run with this variable included as an independent variable.

The fifth hypothesis $\left(\mathrm{H}_{5}\right)$ stated that agency costs were inversely related to the degree of leverage within the firm. The leverage variable (LEV) was not statistically significant in either of the univariate or multivariate analysis performed against ATO. LEV was similarly not statistically significant in the univariate model when regressed against SGA but was significant $(p<5 \%)$ in the multivariate model. Given that LEV was only statistically significant in three of the four models, the fifth hypothesis was rejected.

\section{SUMMARY OF RESULTS}

The hypotheses were established to test agency theory as developed by Jensen and Meckling (1976) and its progeny using variables and methodology developed by Ang, Cole, and Lin (1999) and further developed by Singh and Davidson (2003) and Davidson, Bouresli, and Singh (2006). Each hypothesis tested a different variable which the literature indicated would mitigate the agency conflict. The data analysis concluded that the governance mechanisms traditionally proclaimed by the literature to moderate agency costs did not do so in this data set.

\section{RELEVANCE AND CONTRIBUTION}

The relevance and contribution of this research was two-fold. First, it provides the evidence that governance mechanisms were not reducing agency costs in a pre-SOX environment. ${ }^{8}$ It adds to the already established stream of literature related to agency theory. Specifically, in the shadow of the corporate scandals of the late $20^{\text {th }}$ century and the foreground of the passage of SOX, governance variables which have traditionally been viewed as moderators of agency costs appeared to no longer be produce the desired result.

Second, due to the results found above, it provides an analysis which, based on its outcome, is a compelling call for further research related to agency costs during the time period before SOX. In a research environment where there is significant attention given to SOX and its impact on securities markets, researchers cannot lose sight of their role in adding to the body of knowledge to improve corporate behavior. Specifically, given the results above, it is crucial for researchers to investigate why the governance mechanisms which, prior to this research, were largely

\footnotetext{
${ }^{8}$ It is not the purpose of this research to argue that SOX was necessary given these results, rather to investigate the environment that existed prior to its passage.
} 
held to moderate agency costs did not do so in a pre-SOX environment. History without lessons learned is bound to repeat itself. Therefore, it is incumbent upon researchers to learn lessons from this result to prevent it from repetition. That is to say that researchers must determine the cause in the diminution of the efficacy of these governance mechanisms so we can provide normative solutions for the future and prevent a similar result (whether through complacency or outright deception) to occur and, thereby, improve business processes for all.

\section{AUTHOR INFORMATION}

Scott E. Miller is an Assistant Professor of Accounting, Director of Graduate Programs, and Associate Director of the School of Business at Gannon University. Dr. Miller holds a Doctor of Business Administration from Anderson University, a Juris Doctor from the University of Pittsburgh School of Law, and a Bachelor of Science in Accounting, summa cum laude, from Gannon University.

\section{REFERENCES}

1. Agrawal, A. \& Knoeber, C. (1996). Firm performance and mechanisms to control agency problems between managers and shareholders. Journal of Financial and Qualitative Analysis, 31(3), 377-397.

2. Alchian, A. A. \& Demsetz, H. (1972). Production, information costs, and economic organization. The American Economic Review, 62(5), 777-795.

3. Allen, J.W. \& Phillips, G.M. (2000). Corporate equity ownership, strategic alliances, and product market relationships. Journal of Finance, 55(6), 2791-2815.

4. Ang, J.S., Cole, R.A., \& Lin, J.W. (2000). Agency costs and ownership structure. The Journal of Finance, 55(1), 81-106.

5. Barclay, M. \& Holderness, C. (1991). Control of corporations by active blockholders. Journal of Applied Corporate Finance, 4, 68-77.

6. Baysinger, B.D. \& Butler, H.N. (1985). Corporate governance and the board of directors: Performance effects of changes in board composition. Journal of Law, Economics \& Organization, 1(1), 101-124.

7. Bealing, W.E. \& Baker, R.L. (2006). The Sarbanes-Oxley Act: Have we seen it all before? Journal of Business \& Economic Studies, 12(2), 1-10.

8. Belden, S., Fister, T., \& Knapp, B. (2005). Dividends and directors: Do Outsiders reduce agency costs? Business and Society Review, 110(2), 117-180.

9. Berle, A. \& Means, G. (1932). The Modern Corporation and Private Property. McMillan, New York.

10. Bethel, J.E., Liebeskind, J.P., \& Opler, T. (1998). Block share purchases and corporate performance. Journal of Finance, 53(2), 605-632.

11. Botosan, C.A. (1997). Disclosure level and the cost of equity capital. The Accounting Review, 72(3), 323349.

12. Borokhovich, K.A., Brunarski, K., Harman, Y., \& Kehr, J.B. (2005). Dividends, corporate monitors and agency costs. The Financial Review, 40, 37-65

13. Brunarski, K., Harman, Y., \& Kehr, J.B. (2004). Agency costs and the dividend decision. Corporate Ownership \& Control, 1(3), 44-60.

14. Coughlan, A.T. \& Schmidt, R.M. (1985). Executive compensation, management turnover, and firm performance. An empirical investigation. Journal of Accounting and Economics, 7(1/2/3), 43-66.

15. Cullinan, C. (2004). Enron as a symptom of audit process breakdown: Can the Sarbanes-Oxley Act cure the disease? Critical Perspectives on Accounting, 15(6/7), 853-864.

16. Dallas, L.L. (1996). The relational board: three theories of corporate boards of directors. The Journal of Corporation Law, 22(1), 1-25.

17. Dalton, D.R., Daily, C.M., Ellstrand, A.E., \& Johnson, J.L. (1998). Meta-analytic reviews of board composition, leadership structure, and financial performance. Strategic Management Journal, 19.

18. Davidson, W.N., Bouresli, A.K., \& Singh, M. (2006). Agency costs, ownership structure, and corporate governance in pre- and post- IPO firms. Corporate Ownership \& Control, 3(3), 88-95.

19. DeFond, M.L. (1992). The association between changes in client firm agency costs and auditor switching. Auditing: A Journal of Practice \& Theory, 11(1), 16-31.

20. Fama, E.F. (1980). Agency problems and the theory of the firm. Journal of Political Economy, 88(2), 288307. 
21. Fama, E.F. \& Jensen, M. (1983a). Separation of ownership and control. Journal of Law and Economics, 26, 301-325.

22. Fama, E.F. \& Jensen, M. (1983b). Agency problems and residual claims. Journal of Economics, 26, 327350 .

23. Francis, J.R. \& Wilson, E.R. (1988). Auditor changes: A joint test of theories relating to agency costs and auditor differentiation. The Accounting Review, 63(4), 663-682.

24. Gallegos, F. (October, 2004). Corporate governance practices must not compromise auditor independence. Internal Auditor, 37-41.

25. Gavious, I. (2007). Alternative perspectives to deal with auditors' agency problem. Critical Perspectives on Accounting, 18(4), 451-467.

26. Gujarati, D. N. (2003). Basic Econometrics (4th ed.). Boston, MA: McGraw-Hill.

27. Hermalin, B.E. \& Weisbach, M.S. (1988). The determinants of board composition. Rand Journal of Economics, 19(4), 589-606.

28. Hermalin, B.E. \& Weisbach, M.S. (1991). The effects of board composition and direct incentives on firm performance. Financial Management, 20(4), 101-112.

29. Holderness, C. \& Sheehan, D. (1985). Raiders or saviors? The evidence of six controversial investors. Journal of Financial Economics, 14, 555-579.

30. Jensen, M. \& Meckling, W. (1976). Theory of the firm: Managerial behavior, agency costs and ownership structure. Journal of Financial Economics, 3, 305-360.

31. Khanna, T., Palepu, K.G. \& Srinivasan, S. (2004). Disclosure practices of foreign companies interacting with U.S. markets. Journal of Accounting Research, 42(2), 475-508.

32. Leuz, C. (2007). Was the Sarbanes-Oxley Act of 2002 really this costly? A discussion of evidence from event returns and going-private decisions. Journal of Accounting and Economics, 44(1/2), 146-165.

33. Pearce, J.A. \& Zahra, S.A. (1992). Board composition from a strategic contingency perspective. Journal of Management Studies, 29(4), 411-438.

34. Pfeffer, J. (1973). Size composition and functions of hospital boards of directors: A study of organization environment linkage. Administrative Science Quarterly, 18(3), 349-364.

35. Radin, R.F. \& Stevenson, W.B. (2006). Comparing mutual fund governance and corporate governance. Corporate Governance, 14(5), 367-376.

36. Sarbanes-Oxley Act of 2002, Pub. L. No. 107-204, 116 Stat. 745 (codified as amended in scattered sections of 15 U.S.C.).

37. Shome, D.K. \& Singh, S. (1995). Firm value and external blockholdings. Financial Management, 24(4), 314.

38. Singh, M. \& Davidson, W.N. (2003). Agency costs, ownership structure and corporate governance mechanisms. Journal of Banking \& Finance, 27(5), 793-816.

39. Stock, J.H. \& Watson, M.W. (2007). Introduction to econometrics (2nd ed.). New York: Pearson Education, Inc. 